\title{
Natural Wild Hosts of Sweet potato feathery mottle virus Show Spatial Differences in Virus Incidence and Virus-Like Diseases in Uganda
}

\author{
A. K. Tugume, S. B. Mukasa, and J. P. T. Valkonen
}

First author: Department of Applied Biology, P.O. Box 27, FIN-00014 University of Helsinki, Finland, and Department of Botany, Faculty of Science, Makerere University, P.O. Box 7062 Kampala, Uganda; second author: Department of Crop Science, Faculty of Agriculture, Makerere University, Uganda; and third author: Department of Applied Biology, University of Helsinki, Finland.

Accepted for publication 24 January 2008.

ABSTRACT

\begin{abstract}
Tugume, A. K., Mukasa, S. B., and Valkonen, J. P. T. 2008. Natural wild hosts of Sweet potato feathery mottle virus show spatial differences in virus incidence and virus-like diseases in Uganda. Phytopathology 98: 640-652.

Sweet potato feathery mottle virus (SPFMV, genus Potyvirus) is globally the most common pathogen of sweetpotato. An East African strain of SPFMV incites the severe 'sweetpotato virus disease' in plants co-infected with Sweet potato chlorotic stunt virus and threatens subsistence sweetpotato production in East Africa; however, little is known about its natural hosts and ecology. In all, 2,864 wild plants growing in sweetpotato fields or in their close proximity in Uganda were observed for virus-like symptoms and tested for SPFMV in two surveys (2004 and 2007). SPFMV was detected at different incidence in 22 Ipomoea spp.,
\end{abstract}

Hewittia sublobata, and Lepistemon owariensis, of which 19 species are new hosts for SPFMV. Among the SPFMV-positive plants, $\approx 60 \%$ displayed virus-like symptoms. Although SPFMV incidence was similar in annual and perennial species, virus-like diseases were more common in annuals than perennials. Virus-like diseases and SPFMV were more common in the eastern agroecological zone than the western, central, and northern zones, which contrasted with known incidence of SPFMV in sweetpotato crops. The data on a large number of new natural hosts of SPFMV detected in this study provide novel insights into the ecology of SPFMV in East Africa.

Additional keywords: Convolvulaceae, diversity, epidemiology, Ipomoea batatas, Potyviridae.
The natural hosts of viruses that cause significant economical losses in cultivated plants are largely unknown, which hinders the understanding of virus ecology and hampers the design of appropriate virus control measures $(13,31,78)$. The problem is pronounced in areas where the wild species related to the cultivated crops are abundant and constitute a potential virus reservoir $(16,20)$. Examples of economically harmful plant viruses in wild hosts include cereal or barley yellow dwarf viruses (CYDVs or BYDVs, respectively) in grasses $(18,21,33,63)$, Cucumber mosaic virus in Barbarea vulgaris $\mathrm{R}$. Br. and various weeds of family Solanaceae (36), different viruses of brassica crops in Brassica nigra Koch (73), Grapevine fan leaf virus in Bermudagrass (Cynodon spp.) (37), Potato leafroll virus (PLRV) on hairly nightshade (Solanum sarrachoides) (2), Pepper veinal mottle virus in Thornapple (Datura stramonium) (72), and Cauliflower mosaic virus in cruciferous plants (22). The wild plant species may act as alternative hosts for feeding or reproduction of virus vectors, reservoirs of the virus, or both (38).

A year-round growth of virus-susceptible weeds at a close distance from cultivation readily crossed by the insect vectors is assumed to be a major factor behind the significance of wild plants in the epidemiology of viruses in agroecosystems $(20,38$, 59,78). An example was demonstrated with green peach aphid species (Myzus persicae), which, upon feeding on PLRV-infected hairly nightshade, transmitted the virus from hairly nightshade to potato at a greater rate than from potato to potato or from potato to hairly nightshade (2). On the other hand, spillover of viruses from annual alien hosts to perennial natives (62) has been

Corresponding author: J. P. T. Valkonen; E-mail address: jari.valkonen@helsinki.fi

doi:10.1094/PHYTO-98-6-0640

(c) 2008 The American Phytopathological Society implicated in altering plant community dynamics by reversing native dominance of some grassland communities $(11,49,50)$. The possible role of viruses at the interface between indigenous vegetation and cultivated plants as modulators of plant ecosystems also has been suggested in a recent study (77).

Sweetpotato (Ipomoea batatas (L.) Lam.) is grown throughout the tropics and subtropics (35), with a global annual production of $\approx 124$ million tons, making it the world's third most important root crop after potato (S. tuberosum L.) and cassava (Manihot esculenta Crantz) (19). Sweetpotato is particularly important in developing countries where it provides household food security and is a famine reserve crop (79). It is an ideal crop for subsistence agriculture due to its high productivity in poor soils and suitability for piece-meal harvesting (40). In Africa, production is concentrated in countries around Lake Victoria, where Uganda is the biggest producer and the third in the world after China and Nigeria (19). However, the subsistence sweetpotato production is endangered by viruses, especially Sweet potato feathery mottle virus (SPFMV) (genus Potyvirus, family Potyviridae), the most common pathogen of the crop in East Africa and worldwide $(40,71)$.

SPFMV is transmitted by several aphid species (69) in a nonpersistent manner $(43,66,68)$. Regardless of whether or not a plant is a suitable host for aphid feeding or reproduction, the 'sampling' probes allow aphids to acquire or transmit nonpersistently transmitted viruses and the subsequent inoculation of susceptible host plants $(56,60)$. Studies in Uganda have shown that the aphid species (M. persicae and Aphis gossypii) that efficiently transmit SPFMV in sweetpotato rarely colonize the sweetpotato plants (14). Inside the sweetpotato crop, few aphids were trapped and the numbers captured relative to trap height and distance from the center of the fields were similar, which suggested that the captured individuals were itinerant alate aphids 
originating from other hosts, probably wild plants growing nearby. Although aphids remain viruliferous for only a short period (within seconds to a few minutes) after acquisition of nonpersistent viruses (57), transmission of SPFMV in sweetpotato seems to be efficient.

Most cultivars of sweetpotato grown in Uganda are naturally resistant to SPFMV. The plants show only mild initial symptoms from which they may recover and, consequently, contain low virus titers $(4,29,54)$. However, the resistance of sweetpotato plants to SPFMV is broken down following co-infection of the plants with the unrelated, whitefly-transmitted Sweet potato chlorotic stunt virus (SPCSV; genus Crinivirus, family Closteroviridae) $(29,41)$ that also is common in East Africa. The interaction of the two viruses results in sweetpotato virus disease (SPVD) $(26,66)$, characterized by a $\approx 600$-fold increase in the titer of SPFMV $(17,41,54)$, development of severe disease symptoms, and a yield reduction of 50 to $98 \%(32,54,58)$. SPVD was observed in Uganda already in the 1950s (67) and is still a major disease endangering subsistence sweetpotato production there (40).

Sweetpotato plants in East Africa, including Uganda, are predominantly infected with a unique East African (EA) strain of SPFMV (SPFMV-EA) (44). The EA strain is geographically confined to East Africa and only recently has been found outside the region in Spain (75) and Vietnam (34). In contrast, the three other strains of SPFMV (russet crack [RC], common [C], and ordinary [O]) are unrestricted geographically, and nearly identical isolates of these strains are found worldwide (71). These strains can be distinguished by phylogenetic analysis of the coat protein encoding sequence $(44,71)$. In Uganda, where the $\mathrm{O}$ and RC strains are rare or not found, SPFMV-EA can be detected with antibodies that do not recognize SPFMV-C that also occurs there (55).

The host range of SPFMV, as studied by experimental inoculation, is limited largely to Ipomoea spp. Inoculation with SPFMV results in systemic infection in I. incarnata (Vahl.) Choisy, I. nil (L.) Roth, I. purpurea (L.) Roth, and I. setosa Kerr. With some isolates, local or systemic infection is observed in Nicotiana benthamiana Domin. and Chenopodium amaranticolor Coste \& Reyn. (12,46). However, little is known about the infection of Ipomoea spp. with SPFMV in the field. Ipomoea is the largest genus in the family Convolvulaceae (morning glory) that comprises 50 to 56 genera with 1,600 to 1,700 species exhibiting a rich diversity of morphological characteristics and occupying a wide range of ecological habitats (47). Members of this family are distributed throughout the world, mainly the tropics. In Louisiana, United States, the perennial wild plants of I. trichocarpa Ell. infected with SPFMV can act as a natural reservoir of SPFMV for sweetpotato and probably also the annual wild species such as $I$. hederacea Jacq., I. hederifolia L., I. lacunosa L., and I. wightii (Wall.) Choisy that also are infected with SPFMV in the field (15). In East Africa, over 89 species of Ipomoea $(9,76)$ and several species of other genera of Convolvulaceae are known to occur, including one species each of the genera Hewittia (Wight \& Arn) and Lepistemon (Blume) (1,76). In Uganda, a small survey showed that I. eriocarpa $\mathrm{R}$. Br., I. hederifolia L., and I. tenuirostris Choisy are infected with SPFMV in the Mpigi district in the central zone of the country $(39,40)$. Besides the two aforementioned studies, there are no other reports that we are aware of on surveys of SPFMV in wild species.

The aim of this study was to assess infection of wild plant species (family Convolvulaceae) with SPFMV-EA in the different agroecological zones of Uganda and, hence, identify natural hosts of the local SPFMV strain and its prevalence in them. Plants growing as weeds in sweetpotato fields or in their immediate proximity were examined for virus-like symptoms and serologically tested for SPFMV using antibodies that recognize SPFMVEA. The presence of SPFMV was verified by reverse-transcription polymerase chain reaction (RT-PCR) and sequencing in a number of plants. Assessment was carried out in 2 years and, in total, 2,864 plants of 27 species were tested to obtain a more reliable picture of the possible differences in SPFMV incidence in different species and agroecological zones. This study revealed 19 new natural host species for SPFMV and provides the first insights into the overall ecology and epidemiology of SPFMV in East Africa.

\section{MATERIALS AND METHODS}

Field surveys and sampling. Four agroecological zones of Uganda (namely, the central (Lake Victoria basin), eastern, northern, and western zone) that reflect different patterns of SPFMV incidence in cultivated sweetpotato $(3,5,53)$ were surveyed for wild Ipomoea spp. and SPFMV-EA. From each agroecological zone, two to eight districts were chosen randomly and surveyed for plants that were displaying virus-like symptoms or were apparently healthy looking. The surveys were carried out in June to August 2004 and April to June 2007 in 22 and 18 districts, respectively (Fig. 1). Using "an administrative map of Uganda," a transect line that would divide a given district fairly into two equal portions was drawn. The transect followed a major road when possible, although the sites (radii 30 to $100 \mathrm{~m}$ ) where the actual sampling took place were located at 100 to $300 \mathrm{~m}$ on either side of the road. Plant samples were identified by searching in thickets, bushes, sedges, bogs, grasslands, or rock-foots at edges of crop fields. Sampling sites were preferentially close (less than $30 \mathrm{~m}$ ) to a sweetpotato field, a previous sweetpotato field, or an abandoned sweetpotato field. In some cases, the site of collection was a sweetpotato field in which the wild plants were growing naturally as weeds. An equal number (three to five) of plants expressing virus-like symptoms and those that were symptomless were sampled from each site. However, because, in most cases, fewer symptomatic than symptomless plants were observed, all symptomatic plants observed under these surveys were sampled. Only symptomless plants were sampled from sites where no virus-like symptoms were observed. Because of the creeping or climbing growth habit of many members of Convolvulaceae, care was taken not to sample the same plant more than once. The number of plant species observed per site ranged from one to four. On average, 10 plants (belonging to one or more species) were collected from each site. With a total of six to eight sampling sites located 10 to $16 \mathrm{~km}$ from each other, 70 plants, on average, were sampled from an entire district so that sampling provided a representative coverage of the district.

Plant materials and taxonomic identification. Plants initially were identified during the field surveys only by close examination for distinguishing features of family Convolvulaceae. The features used for this purpose included unlobed trumpet-shaped flower petals, production of milky latex, a creeping or twining growth habit, and an alternate phyllotaxy (76). The plants later were identified to species level according to the taxonomic keys described by Verdcourt (76) and using reference herbarium collections available at the Department of Botany Herbarium, Makerere University.

In all, 5 to 10 leaves (preferably those with virus-like symptoms) and two to five cuttings (length 10 to $25 \mathrm{~cm}$ ) were sampled from each plant. Leaves were used for serological testing of SPFMV. Cuttings were planted and rooted in an insect-proof screenhouse at the Makerere University Agricultural Research Institute, Kabanyolo (MUARIK) to allow further critical observations of virus-like symptoms on new growth and repeated testing for SPFMV. Because most wild plant species in this study were prone to wilting after excision, it was necessary to transport the cuttings to MUARIK very soon. Sampling activities commenced in the early morning hours just before sunrise (between 0630 and $0700 \mathrm{~h}$ ) so as to minimize the impact of wilting. Wilting was further minimized by defoliating the cuttings after excision from their main stems. 
Detection of SPFMV. Nitrocellulose membrane enzyme-linked immunosorbent assay (NCM-ELISA) was used for serological detection of SPFMV with polyclonal antibodies provided by the International Potato Centre (CIP), Lima, Peru. These antibodies detect SPFMV-EA but not SPFMV-C (55). The kit also contained NCM strips spotted with sap from SPFMV-positive and noninfected control sweetpotato plants. Leaf discs $(2 \mathrm{~cm}$ in diameter) were taken from five to seven leaves that were sampled from the field, combined, and tested for SPFMV as described (27). Testing was repeated using the seven topmost leaves of plants established in the screenhouse.

Scions of 28 wild plants that were seronegative for SPFMV but expressed virus-like symptoms, and scions from 30 plants that were symptomless and seronegative, were grafted onto 2-weekold plants of I. setosa, a sensitive indicator of SPFMV $(12,23)$, so as to enhance the chances to detect the virus $(7,53,70)$. The grafted I. setosa plants were observed for virus symptoms and tested for SPFMV by NCM-ELISA 4 weeks after grafting.

The presence of SPFMV was verified in 41 seropositive samples by RT-PCR. Total RNA was extracted using TRIzol Reagent (Invitrogen, UK) according to the manufacturer's instructions from $200 \mathrm{mg}$ of leaf tissue. First-strand cDNA was synthesized on $3 \mu \mathrm{g}$ of total RNA with an oligo-dT ${ }_{25}$ primer and Moloney murine leukemia virus (M-MuLV) reverse transcriptase RNase $\mathrm{H}^{-}$(Finnzymes Oy, Finland) according to the manufacturer's instructions. The cDNA was diluted 10-fold and aliquots were used in PCR. The 3'-proximal part of the SPFMV genome $(\approx 1.8 \mathrm{~kb})$ excluding the poly(A) tail was PCR amplified using a universal potyvirus-specific, degenerate forward primer (PVD-2) (28) and a SPFMV-specific reverse primer 10820R, as described
(71). PCR products from several samples were cloned into pCRBlunt plasmid using a Zero Blunt PCR Cloning Kit (Invitrogen), sequenced and compared by BLAST search with existing sequences available in the National Center for Biotechnology Information (NCBI) database.

Statistical analyses. Data on field incidence of virus-like symptoms and SPFMV were recorded in binary form as 0 and 1. These data were analyzed with generalized linear models (GLM) as implemented in SAS statistical software (version 9.1) (65). The evaluation of the main effects-plant species, zone, and year of sampling - on SPFMV incidence and the incidence of symptoms were analyzed for all 24 sampled host species. The analysis of disease symptoms also included SPFMV as a main effect. Interaction effects for virus incidence and incidence of virus-like disease symptoms were analyzed with a data set consisting of the eight most common host species that were observed in all agroecological zones. Nonsignificant interactions were excluded from the model in a backward stepwise manner. A separate analysis was performed to compare the incidence of SPFMV in annual versus perennial wild plants. Excluding plants of one biannual plant species, a data set comprising plants belonging to 23 species that were either annual or perennial was used to asses the effect of plant lifecycle. The effect of host plant species on the incidence of SPFMV was investigated by comparing SPFMV incidences of different host species.

\section{RESULTS}

Natural habitats of the collected plants. In all, 1,640 and 1,224 wild plants of the family Convolvulaceae were collected in

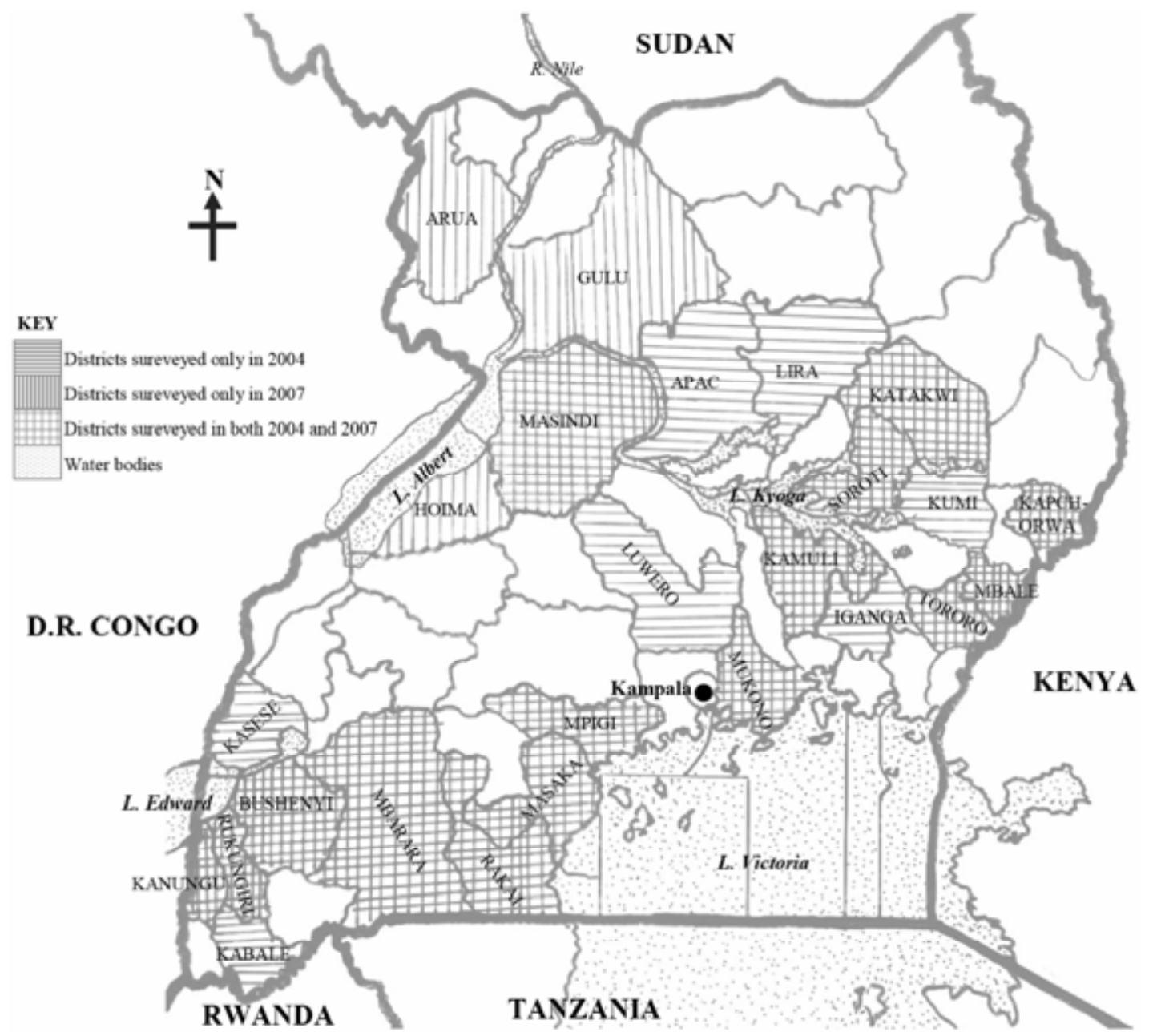

Fig. 1. Districts surveyed for wild species of Convolvulaceae and Sweet potato feathery mottle virus in Uganda. 
2004 and 2007, respectively, for virus testing from their natural habitats in sweetpotato fields or their close proximity in four agroecological zones where sweetpotato crops are grown in Uganda. The wild plants which were SPFMV positive represented 22 species of genus Ipomoea (1,949 plants tested) or belonged to Hewittia sublobata (687 plants) or Lepistemon owariensis (97 plants) (Table 1). In addition, the 25, 42, and 64 plants of $I$. fistulosa Mart. ex Choisy, Astripomoea grantii (Rendel) Verdc, and A. hyoscyamoides (Vatke) Verdc, respectively (family Convolvulaceae), that also were assessed in this study expressed no virus-like symptoms and consistently tested negative for SPFMV (data not shown). They are not further considered hereafter.

Of the 24 species in which SPFMV was detected, 20 species were found in the districts of the eastern zone, whereas 14 and 12 species were encountered in the western and central zones, respectively (Table 2). Only seven wild species of Convolvulaceae were found and sampled in the northern zone (Table 2). Eight species (I. aquatica, I. blepharophylla, I. crepidiformis, I. poly- morpha, I. repens, I. sinensis, I. spathulata, and I. stenobasis) were exclusively observed in the eastern zone (Table 2). On the other hand, I. purpurea, I. grantii, and I. cordofana were observed exclusively in the western, central, and northern zones, respectively (Table 2). Most of these plant species are perennial climbing herbs (Table 1), a growth habit that is common in Convolvulaceae (76); however, six annual species (I. cordofana, I. eriocarpa, I. hederifolia, I. purpurea, I. sinensis, and I. velutipes) and one biannual species (I. polymorpha) (1) also were encountered during the field surveys (Table 1).

In all the agroecological zones surveyed, the plants were collected from a wide range of natural habitats (Fig. 2; Table 1). The great majority of the tested plants grew as weeds in sweetpotato fields or at edges of the fields, in abandoned sweetpotato fields, or in cassava, maize, or legume fields close to sweetpotato plots (Fig. 2A). I. cairica (Fig. 2B), I. obscura (Fig. 2C), I. tenuirostris (Fig. 2D), and H. sublobata (Fig. 2E) were common weeds in sweetpotato, cassava, and maize fields. They also were

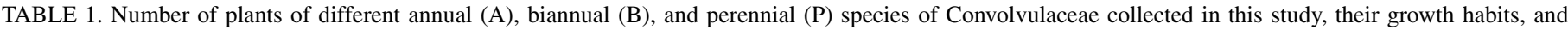
typical natural habitats in Uganda

\begin{tabular}{|c|c|c|c|c|}
\hline Plant species name & Number $^{\mathrm{a}}$ & Lifecyle $^{b}$ & Growth habit ${ }^{\mathrm{c}}$ & $\begin{array}{l}\text { Common habitats from which } \\
\text { the plants were collected }\end{array}$ \\
\hline Ipomoea acuminata (Vahl) Roem. \& Schultes & $157(55+102)$ & $\mathrm{P}$ & Twining/climbing herb & $\begin{array}{l}\text { Forest mosaics, grasslands, thickets, } \\
\text { hedges, ornamental }\end{array}$ \\
\hline I. aquatica Forsk & $24(12+12)$ & $\mathrm{P}$ & Floating herb, semi-succulent & Ponds, swamps, marshes \\
\hline I. blepharophylla Hall. f. & $14(14+0)$ & $\mathrm{P}$ & Prostrate from a woody rootstock & $\begin{array}{l}\text { Mostly in burnt Combretum woodlands, } \\
\text { grasslands }\end{array}$ \\
\hline I. cairica (L.) Sweet & $220(99+121)$ & $\mathrm{P}$ & Twining/climbing/creeping herb & $\begin{array}{l}\text { Forest edges, hedges, marshes, } \\
\text { lakeshores, garden weed }\end{array}$ \\
\hline I. cordofana DC. & $10(10+0)$ & A & Prostrate herb, weakly twining & $\begin{array}{l}\text { Disturbed habitats, Acacia bushland, } \\
\text { grasslands }\end{array}$ \\
\hline I. crepidiformis Hall. $\mathrm{f}$. & $30(18+12)$ & $\mathrm{P}$ & Erect short shrub & $\begin{array}{l}\text { Dry grasslands, shallow soils around } \\
\text { rocks }\end{array}$ \\
\hline I. eriocarpa $\mathrm{R} . \mathrm{Br}$. & $134(134+0)$ & A & Climbing herb & $\begin{array}{l}\text { Disturbed bushland, grasslands, garden } \\
\text { weed }\end{array}$ \\
\hline I. fistulosa Mart. ex Choisy & $25(25+0)$ & $\mathrm{P}$ & Erect tall shrub & Deciduous bushlands, ornamental \\
\hline I. grantii Oliver \& Hiern & $9(9+0)$ & $\mathrm{P}$ & Climbing herb & Riverine forest grassland \\
\hline I. hederifolia $\mathrm{L}$. & $47(13+34)$ & A & Twining/climbing herb & Waste places, forest edges, hedges \\
\hline I. hildebrandtii Vatke & $17(11+6)$ & $\mathrm{P}$ & Erect tall shrub & $\begin{array}{l}\text { Deciduous bushlands, grasslands, } \\
\text { ornamental }\end{array}$ \\
\hline I. involucrata P. Beauv. & $78(78+0)$ & $\mathrm{P}$ & Twining/climbing herb & Forests, woodlands, land under fallow \\
\hline I. obscura (L.) Ker-Gawl & $154(79+75)$ & $\mathrm{P}$ & Twining/climbing herb & $\begin{array}{l}\text { Dry woodlands, grasslands, hedges, } \\
\text { garden weed }\end{array}$ \\
\hline I. polymorpha Roem. \& Schultes & $10(10+0)$ & B & Erect/prostrate herb & $\begin{array}{l}\text { Moister bushland on shallow soils, } \\
\text { grasslands }\end{array}$ \\
\hline I. purpurea (L.) Roth & $24(10+14)$ & A & Twining/climbing herb & Waste places, garden weed \\
\hline I. repens Roth & $27(24+3)$ & $\mathrm{P}$ & Semi-woody climber & $\begin{array}{l}\text { Marshes, shallow moist soils } \\
\text { surrounding rocks }\end{array}$ \\
\hline I. rubens Choisy & $37(27+10)$ & $\mathrm{P}$ & Semi-woody twiner/climber & Marshes, bogs, papyrus swamps \\
\hline I sinensis (Desr.) Choisy & $374(143+231)$ & A & Prostrate/twining herb & $\begin{array}{l}\text { Seasonally flooded grasslands, garden } \\
\text { weed }\end{array}$ \\
\hline I. spathulata Hall. f. & $42(15+27)$ & $\mathrm{P}$ & $\begin{array}{l}\text { Partially erect shrub, twining } \\
\text { branches }\end{array}$ & Shallow dry rocky soils, ornamental \\
\hline I. stenobasis Brenan & $23(13+10)$ & $\mathrm{P}$ & Twining/climbing herb & Grasslands, hedges, ornamental \\
\hline I. tenuirostris Choisy & $395(230+165)$ & $\mathrm{P}$ & Twining/climbing herb & $\begin{array}{l}\text { Woodlands, grasslands, thickets, } \\
\text { pasture/garden weed }\end{array}$ \\
\hline I. velutipes Welw. Ex Rendle & $10(10+0)$ & A & Twining/climbing, herb & $\begin{array}{l}\text { Disturbed bushland, grasslands, weed in } \\
\text { A crops }\end{array}$ \\
\hline I. wightii (Wall.) Choisy & $113(62+51)$ & $\mathrm{P}$ & Twining/climbing/prostrate herb & $\begin{array}{l}\text { Forest edges, grasslands, land under } \\
\text { fallow }\end{array}$ \\
\hline Astripomoea grantii (Rendel) & $42(25+17)$ & $\mathrm{P}$ & Erect short shrub & $\begin{array}{l}\text { Shallow moist soils around rocks, } \\
\text { grasslands }\end{array}$ \\
\hline A. hyoscyamoides (Vatke) Verdc & $64(50+14)$ & $\mathrm{P}$ & Erect short shrub & $\begin{array}{l}\text { Shallow moist soils around rocks, } \\
\text { grasslands }\end{array}$ \\
\hline Hewittia sublobata (L. f.) O. Kuntze & $687(420+267)$ & $\mathrm{P}$ & Prostrate herb & $\begin{array}{l}\text { Bushland, grasslands, disturbed habitats, } \\
\text { garden weed }\end{array}$ \\
\hline Lepistemon owariensis (Beauv.) Hall. f. & $97(44+53)$ & $\mathrm{P}$ & Climbing herb & Riverine forests, grasslands, bushlands \\
\hline Total number of plants collected & $2,864(1,640+1,224)$ & $\ldots$ & $\ldots$ & $\ldots$ \\
\hline
\end{tabular}

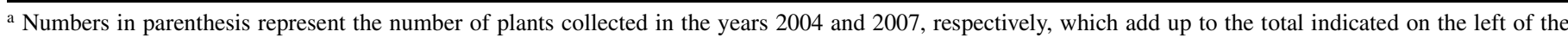
parentheses.

b Descriptions according to Agnew and Agnew (1) and the observations made during the field surveys in this study.

c Descriptions according to Blundel (9) and the observations made during the field surveys in this study. 


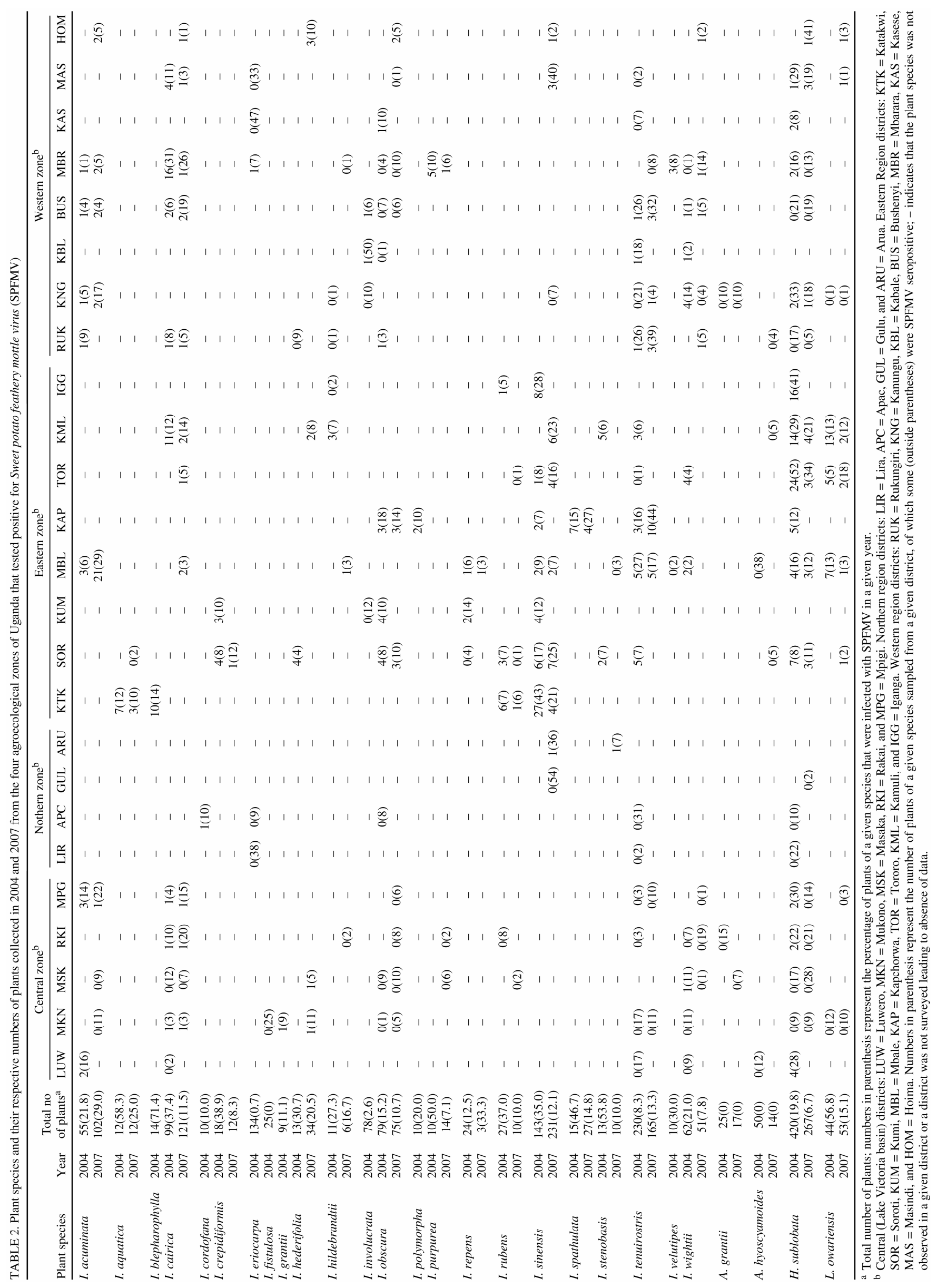


abundant in short to tall savannah grasslands and forest vegetation close to agricultural sites. Other species that were common in such habitats included I. acuminata (Fig. 2F), I. hildebrandtii (Fig. 2G), and I. stenobasis (Fig. 2H). Plants of I. hederifolia (Fig. 2I) were common in waste places and forest edges. On the other hand, some plants were found exclusively in habitats within an aquatic environment (I. aquatica) (Fig. 2J) or waterlogged swampy marshes (I. rubens) (Fig. 2K) that were located close to sweetpotato fields. In addition, plants of $I$. spathulata (Fig. 2L), I. repens (Fig. 2M), and I. crepidiformis (Fig. 2N) were found growing in habitats characterized by shallow soils in rocky environments. Apart from growing naturally in wild environments, species of I. spathulata, I. acuminata, I. hildebrandtii, and I. stenobasis also were domesticated as ornamental plants and, hence, were common around homes and in abandoned homesteads.

Incidence of virus-like symptoms. Out of all the plants that were collected in the two surveys, a total of 367 plants $(13 \%)$ displayed virus-like symptoms in the field. The symptoms included mottling, general chlorosis, chlorotic spots, and vein chlorosis (Fig. 3). Symptom expression varied from plant to plant and from species to species. For instance, I. acuminata mostly exhibited mottling symptoms (Fig. 3F), whereas I. wightii (Fig. 3G), I. rubens (Fig. 3K), I. tenuirostris (Fig. 3L), and I. sinensis (Fig. 3M) mostly exhibited chlorosis. On the other hand, species such as I. cairica, I. eriocarpa, I. spathulata, I. hildebrandtii, I. involucrata, and L. owariensis rarely exhibited any virus-like disease symptoms in the field. However, in the screenhouse, mild symptoms of mottling were observed on a few plants of $I$. cairica (Fig. 3H) and I. spathulata (Fig. 3I). Variability in symptom expression was expected because it is a function of variable factors such as environmental conditions, virus strain, host plant species or genotype, age, and the host's physiological state (16).

Symptoms were observed in the wild species in all other districts surveyed except those of the northern zone (Lira and Apac in 2004 and Gulu and Arua in 2007) (Fig. 4). In both years, incidence of symptoms was higher in districts of the eastern zone than those of the central and western zones (Fig. 4). For example, in the eastern zone, it ranged from $19 \%$ in Kapchorwa to $49 \%$ in Kamuli in 2004 (Fig. 4A) whereas, in 2007, it ranged from 14\% in Katakwi to $26 \%$ in Kamuli (Fig. 4B). In the western zone, incidence ranged from $2.8 \%$ in Kabale to $14 \%$ in Mbarara during 2004 (Fig. 4A) and from 5.8\% in Kanungu to $11 \%$ in Bushenyi during 2007 (Fig. 4B). Among the districts of the central zone in Lake Victoria basin, the highest disease incidence was $9.8 \%$ in Mpigi in 2004 and 5.0\% in Mukono in 2007, whereas the lowest incidences of symptomatic plants were 4.0 and $2.8 \%$ in Rakai in both years (Fig. 4A and B). Statistical analysis of data showed no significant difference $(P=0.5956)$ in the incidence of viruslike disease symptoms between the 2 years (Table 3 ). However, zones differed significantly $(P<0.0001)$ (Table 3$)$, with the overall highest incidence in the eastern zone (25\%) compared with the western $(8.4 \%)$ and central $(5.4 \%)$ zones. There also was a significant interaction $(P=0.0361)$ between zones and years with respect to incidence of virus-like disease symptoms (Table 3).

Of the species assessed in 2004, at least one plant each of 21 species displayed virus-like symptoms, whereas the relatively few (9 to 10) assessed plants of three species (I. cordofana, I. grantii, and $I$. polymorpha) expressed no virus-like symptoms (Table 4). In 2007, virus-like disease symptoms were observed in 16 of the 17 species assessed, all of which also had been tested in 2004. There was a significant difference $(P<0.0001)$ between plant species with respect to incidence of virus-like symptoms (Table $3)$. For example, although a large number of 134 plants of $I$. eriocarpa were assessed, only 5 plants $(3.7 \%)$ were found to display virus-like symptoms. On the other hand, 45 plants of the
143 assessed plants of I. sinensis (31.5\%) showed virus-like symptoms (Table 2). In addition, the incidence of symptomatic plants of a species could differ significantly $(P<0.0001)$ between the 2 years (Table 3 ). Overall, the largest numbers of plants expressing virus-like symptoms were found in H. sublobata (89 plants, 13\%), I. sinensis (76 plants, 20\%), I. tenuirostris (42 plants, 11\%), I. acuminata (35 plants, 22\%), and I. obscura (20 plants, $13 \%$ ).

Differences in the incidence of SPFMV between plant species. Of all the plants assessed in this study, 324 plants $(21 \%)$ and 152 plants (13\%) were seropositive for SPFMV in 2004 and 2007, respectively (Table 4). The difference between the 2 years was statistically significant $(P<0.0001)$ (Table 3$)$. Testing samples by NCM-ELISA in triplicate showed a consistent and unambiguous positive reaction with SPFMV antibodies compared with the positive and negative control strips included in the NCMELISA kit. In addition, scions from 53 wild plants that had tested positive for SPFMV were grafted on I. setosa and the grafted $I$. setosa plants developed vein-clearing symptoms and tested SPFMV-positive in NCM-ELISA 4 weeks after grafting, as expected. The presence of SPFMV was further verified by RT-PCR and also by cloning and sequencing of the 3'-proximal genomic RNA region of SPFMV. Comparison to the available sequences in the NCBI database using BLAST search indicated that the sequences from 31 samples constituted the $3^{\prime}$ region of SPFMVEA genomic RNA (data not shown).

At least one plant of 24 species tested in 2004 was infected with SPFMV (Table 2), and sampling and testing of 17 of these species again in 2007 provided consistent results (Table 4). The plant species differed significantly $(P<0.0001)$ in the incidence of SPFMV (Table 6). Considering nine species (I. acuminata, I. cairica, I. eriocarpa, I. obscura, I. sinensis, I. tenuirostris, I. wightii, H. sublobata, and L. owariensis), of which plants were tested in large numbers (at least 97 plants per species) over the 2 years, the overall incidence of SPFMV ranged from $0.7 \%$ in I. eriocarpa to $34 \%$ in L. owariensis (Table 2). The largest numbers of SPFMV-positive plants were detected in H. sublobata (107 plants, 15\%), I. sinensis (78 plants, 21\%), I. cairica (51 plants, 23\%) I. acuminata (42 plants, 27\%), I. tenuirostris (41 plants, $10 \%$ ), and L. owariensis (33 plants, 34\%) in the 2 years (Table 2). In no species were all sampled plants seropositive for SPFMV.

More perennial (17 species, 2,124 plants) than annual (6 species, 599 plants) or biannual species ( 1 species, 10 plants) were found and assessed (Table 1). Comparison of data according to plant lifecycle showed no statistically significant difference $(P=$ $0.6026)$ in the incidence of SPFMV in annuals (16.7\%) and in perennials $(17.6 \%)$ (Table 3$)$. However, there was a significant difference $(P=0.0198)$ in the incidence of virus-like symptoms between annuals (16.3\%) and perennials (12.7\%) (Table 3).

Association between virus-like symptoms and SPFMV infection. Among all the SPFMV-seropositive plants, 58 and $62 \%$ displayed virus-like symptoms in the field in 2004 and 2007, respectively. In many species, all plants displaying virus-like symptoms were seropositive for SPFMV (Table 4). These included I. hildebrandtii, I. purpurea, I. spathulata, and I. stenobasis in both years, I. aquatica and I. obscura in 2004 but not 2007, I. repens in 2007 but not 2004, and I. velutipes that was surveyed only in 2004 (Table 4). Analysis of data showed that plants with virus-like symptoms were likely to be SPFMV seropositive by a $77 \%$ probability, suggesting that the virus-like symptoms were typically, albeit not always, associated with SPFMV infection. Further analysis also showed that plant species differed significantly $(P=0.0056)$ in associating virus-like symptoms with SPFMV infection (Table 3).

Scions of 28 wild plants that were seronegative for SPFMV but expressed virus-like symptoms, and scions from 30 plants that were symptomless and seronegative, were grafted onto I. setosa, 
so to enhance the chances to detect SPFMV $(7,55,70)$. All the graft-inoculated plants of $I$. setosa tested negative for SPFMV 4 weeks post grafting. These data indicated that NCM-ELISA provided reliable information about the incidence of SPFMV-EA in the wild species and that, in some plants, the virus-like disease symptoms were caused by other pathogens or factors than SPFMV-EA.

Of all the plants that were symptomless in the field, 10 and $5.6 \%$ tested positive for SPFMV in 2004 and 2007, respectively (Table 4). Hence, there was a probability of $8.2 \%$ that a symptomless plant could be SPFMV seropositive. Over the 2 years, the largest numbers of symptomless SPFMV-positive plants were encountered in species of I. cairica (39 plants, 19\%), H. sublobata (26 plants, 4.3\%), L. owariensis (26 plants, 29\%), I. sinensis (17 plants, 5.7\%), and I. acuminata (17 plants, 14\%) (Table 2).

Incidence of SPFMV depending on the agroecological zone. No plant sampled in the districts of Lira and Gulu of the northern zone tested positive for SPFMV, whereas at least one plant from each of the other 21 and 17 districts surveyed in 2004 and 2007, respectively, was SPFMV positive (Table 2). Incidence of SPFMV ranged from $1.5 \%$ in Apac (northern zone) to $67 \%$ in Kamuli (eastern zone) in 2004. In 2007, the lowest observed incidence was $1.4 \%$ in Rakai (central zone) and the highest $24 \%$ in Soroti (eastern zone) (Table 2). Differences in SPFMV incidence between years were statistically significant $(P<0.0001)$ (Table $3)$, with the overall incidence higher in 2004 (21\%) than in 2007 (13\%) (Table 2).
Considering all the plants tested over the 2 years, incidence of SPFMV was highest in the districts of the eastern zone $(35 \%)$ compared with $11,4.3$, and $1.3 \%$ in the western, central, and northern zones, respectively (Table 2). Eight species (I. acuminata, I. cairica, I. hederifolia, I. obscura, I. tenuirostis, I. wightii, H. sublobata, and L. owariensis) commonly were found in the eastern, central, and western zones (Table 2) and sampled in relatively large numbers, constituting $68 \%$ of all plants tested over the 2 years. They were used as 'indicators' for comparing the incidence of SPFMV across the three zones. Incidence of SPFMV in these species was high in the eastern zone (47\% in 2004 and $27 \%$ in 2007), and lower in the western (13 and $11 \%$, respectively) and central zones (6.4 and $2.3 \%$, respectively) (Table 2). The differences between zones were statistically significant $(P=0.0001)$ (Table 3$)$. Furthermore, the three agroecological zones differed in the way symptoms were associated with SPFMV infection $(P=0.0252)$ (Table 3$)$. A higher proportion of the SPFMV-infected plants displayed virus-like symptoms in the eastern zone than in the central and western zones.

Plants of the aforementioned eight 'indicator' species either were not observed in the northern zone (I. acuminata, I. cairica, I. hederifolia, I. wightii, and L. owariensis) or, when they were found, all tested negative for SPFMV (I. obscura, I. tenuirostis, and $H$. sublobata) (Table 2). Indeed, few SPFMV-infected plants were detected in the northern zone, where only one plant each of I. cordofana, I. sinensis, and I. stenobasis were found to be seropositive for SPFMV (Table 2).
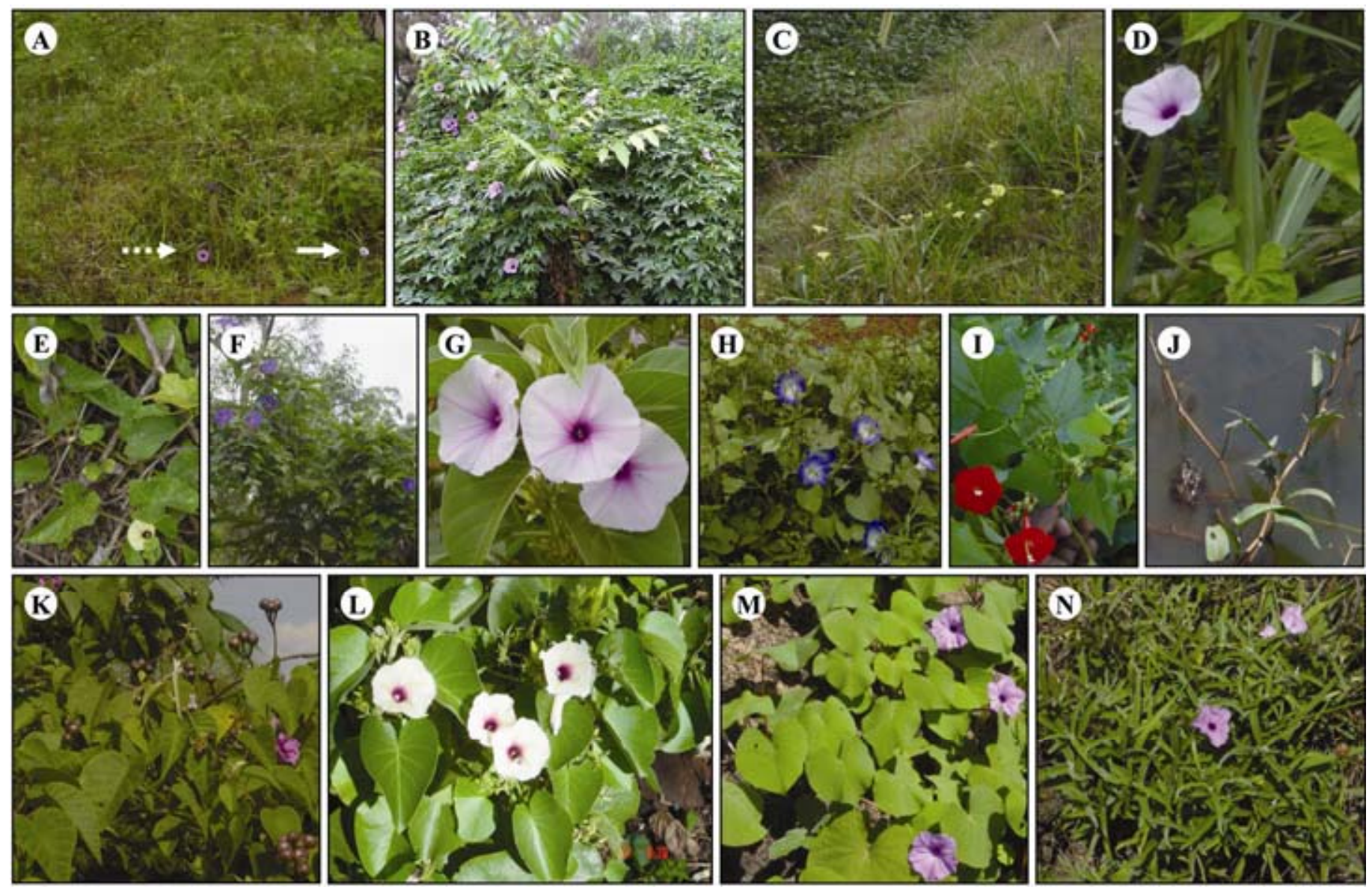

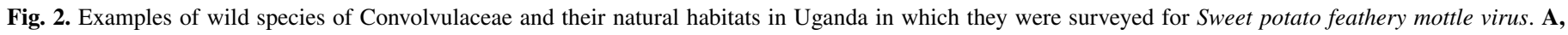

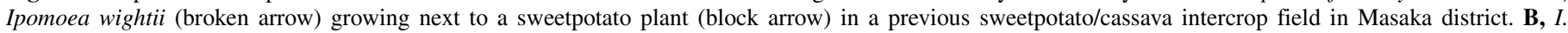

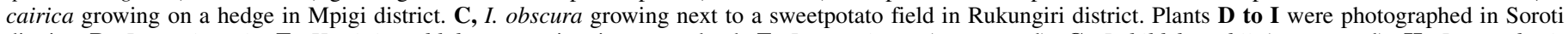

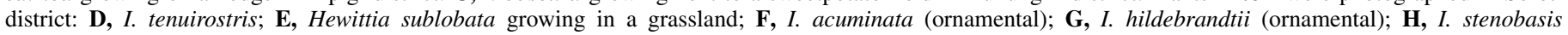

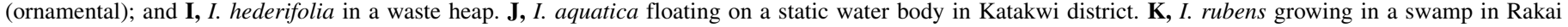

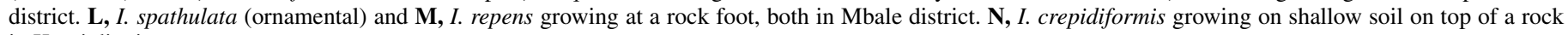
in Kumi district. 


\section{DISCUSSION}

SPFMV is the most widespread and important pathogen of cultivated sweetpotato $(40,46,52,71,74)$. However, studies of SPFMV have concentrated almost exclusively on sweetpotato crops and little is known about the wild hosts of SPFMV. East Africa, especially the Lake Victoria basin, is the second most important sweetpotato production area in the world and Uganda is the world's third biggest sweetpotato producer (19); however, only one preliminary study has reported detection of SPFMV in a few wild species in one district of Uganda (39). A unique EA strain of SPFMV predominates in sweetpotato in Uganda $(44,71)$ and there is an urgent need to gain better understanding of the possible role of the wild species in its ecology.

In this study, 24 wild species of Convolvulaceae were found to be infected with SPFMV in the field in Uganda, of which 19 were identified as hosts of SPFMV for the first time. Only I. eriocarpa, I. hederifolia, I. wightii, and I. tenuirostris previously were known as natural hosts for SPFMV in Uganda $(39,40)$. I. hederifolia and I. wightii are infected with SPFMV also in Louisiana (15). I. purpurea can be infected with SPFMV following experimental inoculation (12) but, in this study, it was found to be infected with SPFMV for the first time in the field. Hence, the study significantly extended the knowledge of natural hosts of SPFMV.
Surveying wild plants for SPFMV in this study was based primarily on serological detection with antibodies that recognize the local SPFMV-EA strain but not the globally distributed SPFMV-C strain that also occurs in Uganda (55). These antibodies also detect SPFMV strains $\mathrm{O}$ and RC but those strains are uncommon or not found in sweetpotato in Uganda $(53,55,71)$. Hence, the survey was focused on the local EA strain of SPFMV, which was confirmed by partial molecular characterization and phylogenetic analysis of 31 isolates. Sensitivity and specificity of the serological testing of wild plants also was verified by graft inoculation to the indicator host I. setosa and subsequent assessment of symptoms and SPFMV in this species. In conclusion, this study provides a comprehensive picture of the occurrence of SPFMV-EA in wild species of Convolvulaceae in Uganda.

All plants that displayed virus-like disease symptoms were sampled because, in all cases, fewer symptomatic plants than symptomless ones were observed in the sampling sites. Results showed that virus-like symptoms were positively correlated with incidence of SPFMV infection in the eastern, central, and western agroecological zones. Only a few symptomless plants were SPFMV infected. However, it was apparent that there were relatively large proportions (41\% in 2004 and 37\% in 2007) of plants that expressed virus-like symptoms in the field but were SPFMV seronegative, which suggested that there also may be other viruses infecting the plants. These results were not explained by
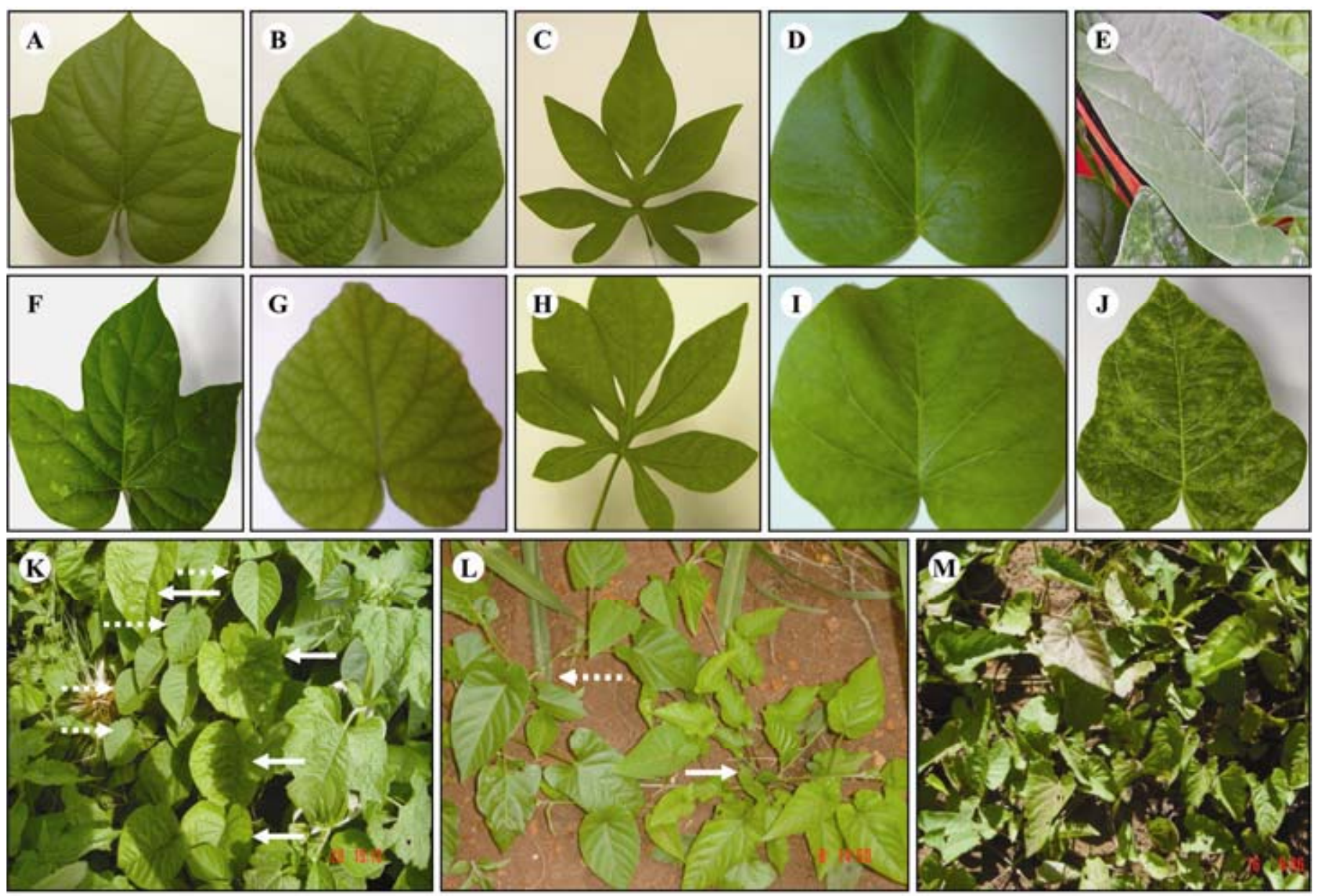

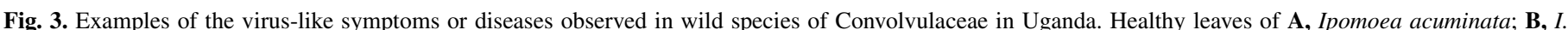

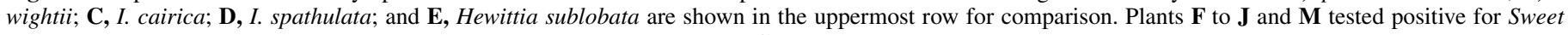

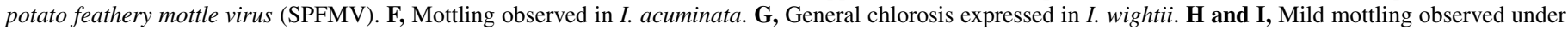

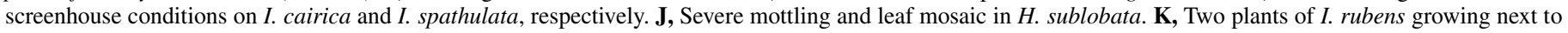

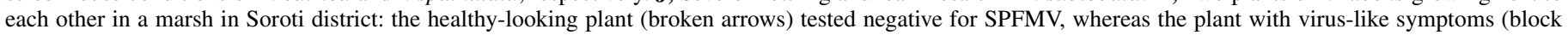

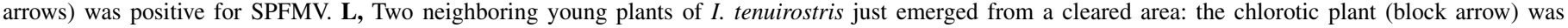

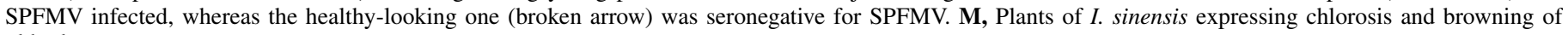
older leaves. 
false negative results due to low virus titers in the wild plants, because graft inoculation of indicator plants (I. setosa) with scions from the wild species and testing the indicators for SPFMV also provided negative results. For instance, African cassava mosaic virus, a whitefly-transmitted virus infecting cassava in eastern and central Africa (45), occurs in H. sublobata (10) and might be one of the viruses causing symptoms in this species in the field. Hence, further studies are required to test the wild species for

A June-August 2004

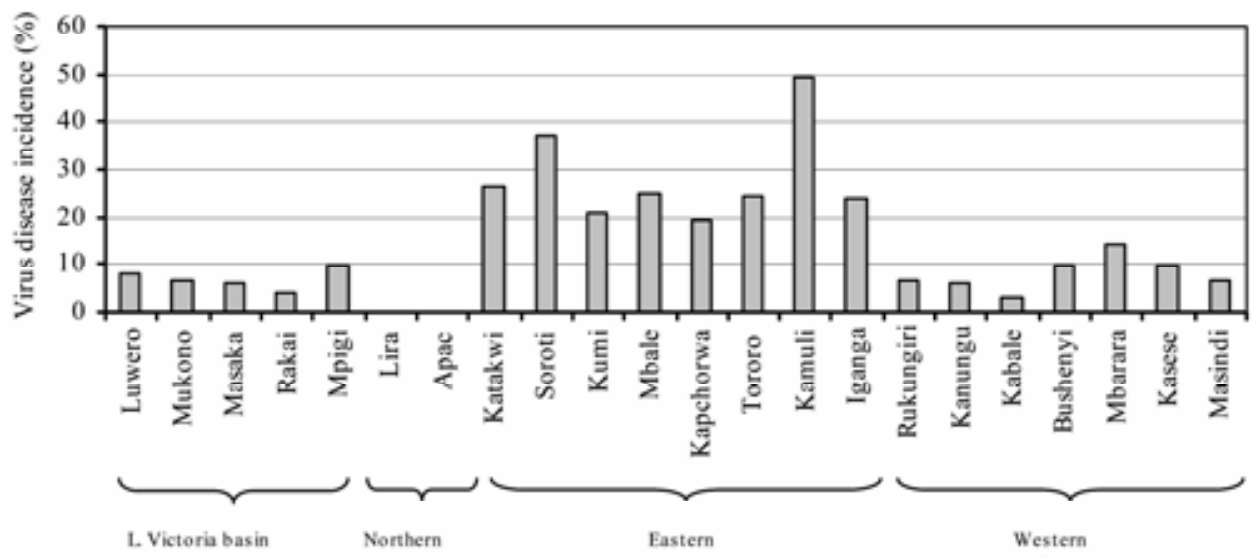

B April - June 2007

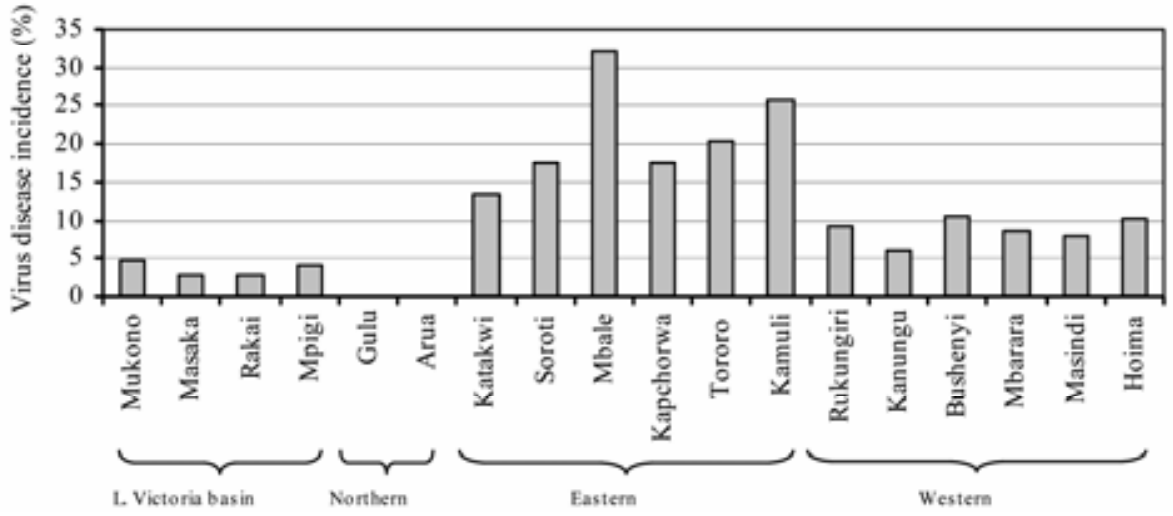

Fig. 4. Overall incidences of virus-like diseases in wild plants of Convolvulaceae in 22 and 18 districts of Uganda in A, 2004 and B, 2007, respectively. For the number of plants observed in each district (Table 2).

TABLE 3. Analysis of the effects of agroecological zone, year of sampling, plant species, and lifecycle on the incidence of virus-like diseases and of Sweet potato feathery mottle virus (SPFMV)

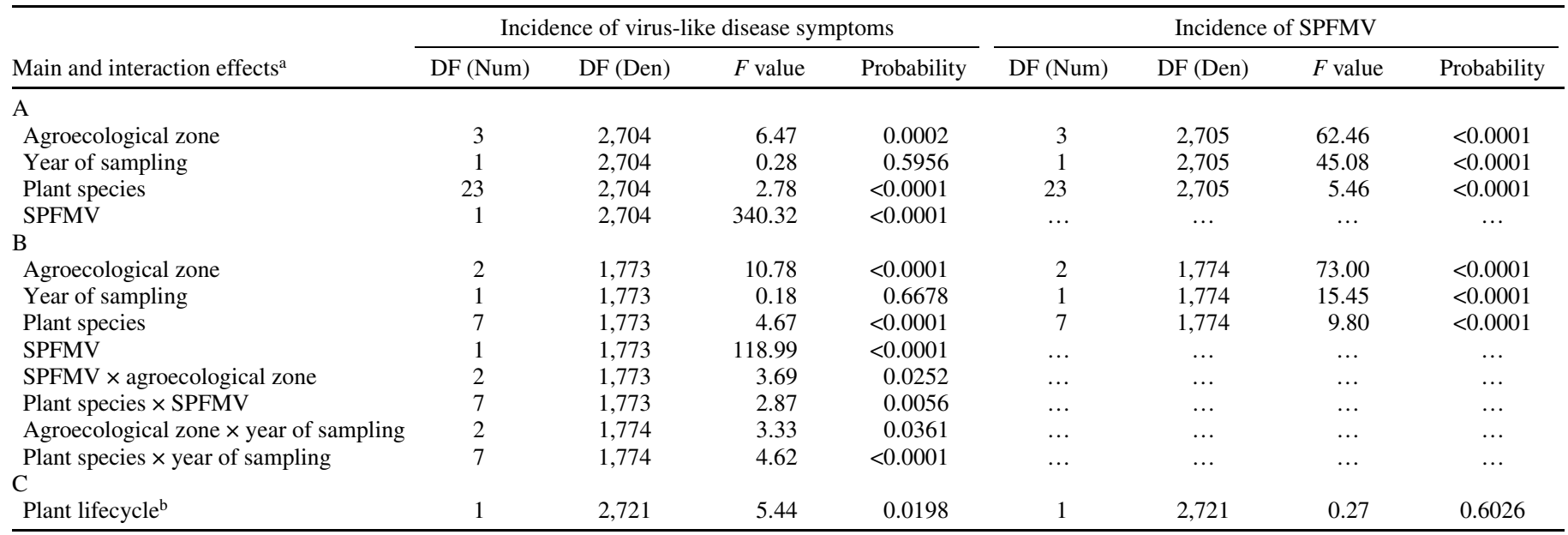

${ }^{a}$ Data from all 24 plant species in which SPFMV was detected were used to analyze the main effects included under A, whereas the results of analysis under B are for only 8 species that were sampled consistently in large numbers in both years and from all zones (except for the northern zone), which allowed analysis of interaction effects.

${ }^{\mathrm{b}}$ All the plants of 23 species were of one of the two forms of lifecycle (annual and perennial) except for 10 plants of I. polymorpha (biannual) which were excluded from this analysis. 
other viruses. Furthermore, in plant species such as those of this study in which virus disease etiology has not been studied extensively, virus-like disease symptoms also could be due to drought, nutritional imbalances, senescence, water-logging, or shading effects by other plants.

The findings indicated that the wild plant species surveyed may be potential perennial reservoirs of SPFMV to cultivated sweetpotato. Most of the SPFMV-infected wild host plants identified in this study are perennials and evergreen $(1,76)$ and grew inside or adjacent to sweetpotato fields which are commonly visited, albeit usually not colonized, by aphids that efficiently transmit SPFMV in sweetpotato (14). Hence, an individual plant could be a virus reservoir for many years, encompassing several sweetpotato growing seasons. The assumption is that a year-round growth of susceptible wild plants ensures host continuity in space and time, facilitating virus spread from wild hosts into agroecosystems $(20,38,78)$. In Louisiana, the perennial wild I. trichocarpa plants are reservoirs of SPFMV throughout sweetpotato growing seasons (15). However, currently, there are no studies to show whether isolates of SPFMV from wild species play a role in the incidence

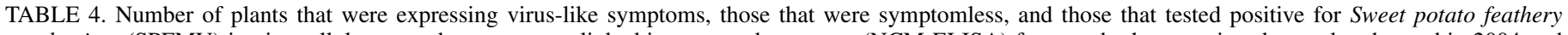

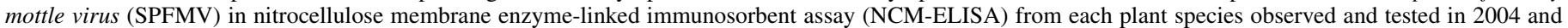
$2007^{\mathrm{a}}$

\begin{tabular}{|c|c|c|c|c|c|c|}
\hline \multirow[b]{2}{*}{ Plant species } & \multirow[b]{2}{*}{ Total no. of plants } & \multicolumn{2}{|c|}{ With virus-like diseases } & \multicolumn{2}{|c|}{ Symptomless plants } & \multirow{2}{*}{$\frac{\text { Overall }}{\text { SPFMV+ }(\%)}$} \\
\hline & & Total $(\%)^{\mathrm{b}}$ & $\mathrm{SPFMV}+{ }^{\mathrm{c}}$ & Total $(\%)^{\mathrm{d}}$ & SPFMV+ $(\%)^{\mathrm{e}}$ & \\
\hline \multicolumn{7}{|l|}{2004} \\
\hline Ipomoea acuminata & 55 & $15(27.3)$ & 60 & $40(73.7)$ & $3(7.5)$ & $12(21.8)$ \\
\hline I. aquatica & 12 & $4(33.0)$ & 100 & $8(67.0)$ & $3(37.5)$ & $7(58.3)$ \\
\hline I. blepharophylla & 14 & $4(29.0)$ & 75 & $10(71.0)$ & $7(70.0)$ & $10(71.4)$ \\
\hline I. cairica & 99 & $9(9.1)$ & 88.9 & $90(90.9)$ & $29(32.2)$ & $37(37.4)$ \\
\hline I. cordofana & 10 & $0(0.0)$ & 0 & $10(100.0)$ & $1(10.0)$ & $1(10.0)$ \\
\hline I. crepidiformis & 18 & $4(22.0)$ & 75 & $14(78.0)$ & $4(28.6)$ & $7(38.9)$ \\
\hline I. eriocarpa & 134 & $5(4.0)$ & 0 & $129(96.0)$ & $1(0.8)$ & $1(0.7)$ \\
\hline I. grantii & 9 & $0(0.0)$ & 0 & $9(100.0)$ & $1(11.1)$ & $1(11.1)$ \\
\hline I. hederifolia & 13 & $5(38.0)$ & 60 & $8(62.0)$ & $1(12.5)$ & $4(30.7)$ \\
\hline I. hildebrandtii & 11 & $1(9.1)$ & 100 & $10(90.9)$ & $2(20.0)$ & $3(27.3)$ \\
\hline I. involucrata & 78 & $3(4.0)$ & 33.3 & $75(96.0)$ & $1(1.3)$ & $2(2.6)$ \\
\hline I. obscura & 79 & $10(12.7)$ & 100 & $69(87.3)$ & $2(2.9)$ & $12(15.2)$ \\
\hline I. polymorpha & 10 & $0(0.0)$ & 0 & $10(100.0)$ & $2(20.0)$ & $2(20.0)$ \\
\hline I. purpurea & 10 & $2(20.0)$ & 100 & $8(80.0)$ & $3(37.5)$ & $5(50.0)$ \\
\hline I. repens & 24 & $7(29.0)$ & 42.8 & $17(71.0)$ & $0(0.0)$ & $3(12.5)$ \\
\hline I. rubens & 27 & $3(11.0)$ & 66.7 & $24(89.0)$ & $8(33.3)$ & $10(37.0)$ \\
\hline I. sinensis & 143 & $45(31.5)$ & 88.9 & $98(68.5)$ & $10(10.2$ & $50(35.0)$ \\
\hline I. spathulata & 15 & $1(7.0)$ & 100 & $14(93.0)$ & $6(42.8)$ & $7(46.7)$ \\
\hline I. stenobasis & 13 & $6(46.0)$ & 100 & $7(54.0)$ & $1(14.3)$ & $7(53.8)$ \\
\hline I. tenuirostris & 230 & $23(10.0)$ & 74 & $207(90.0)$ & $2(0.9)$ & $19(8.3)$ \\
\hline I. velutipes & 10 & $1(10.0)$ & 100 & $9(90.0)$ & $2(22.2)$ & $3(30.0)$ \\
\hline I. wightii & 62 & $10(16.1)$ & 90 & $52(83.9)$ & $4(7.7)$ & $13(21.0)$ \\
\hline Hewitta sublobata & 420 & $67(16.0)$ & 91 & $353(84.0)$ & $22(6.2)$ & $83(19.8)$ \\
\hline Lepistemon owariensis & 44 & $5(11.4)$ & 80 & $39(88.6)$ & $21(53.8)$ & $25(56.8)$ \\
\hline \multicolumn{7}{|l|}{2007} \\
\hline I. acuminata & 102 & $20(20.0)$ & 80 & $82(80.0)$ & $14(17.1)$ & $30(29.0)$ \\
\hline I. aquatica & 12 & $3(25.0)$ & 33.3 & $9(75.0)$ & $2(22.1)$ & $3(25.0)$ \\
\hline I. blepharophylla & - & - & - & - & - & - \\
\hline I. cairica & 121 & $6(5.0)$ & 66.7 & $115(95.0)$ & $10(8.7)$ & $14(11.5)$ \\
\hline I. cordofana & - & - & - & - & - & - \\
\hline I. crepidiformis & 12 & $0(0.0)$ & 0 & $12(100.0)$ & $1(8.3)$ & $1(8.3)$ \\
\hline I. eriocarpa & - & - & - & - & - & - \\
\hline I. grantii & - & - & - & - & - & - \\
\hline I. hederifolia & 34 & $8(24.0)$ & 75 & $26(76.0)$ & $1(3.8)$ & $7(20.5)$ \\
\hline I. hildebrandtii & 6 & $1(17.0)$ & 100 & $5(83.0)$ & $0(0.0)$ & $1(16.7)$ \\
\hline I. involucrata & - & - & - & - & - & - \\
\hline I. obscura & 75 & $10(13.0)$ & 50 & $65(87.0)$ & $4(4.6)$ & $8(10.7)$ \\
\hline I. polymorpha & - & - & - & - & - & - \\
\hline I. purpurea & 14 & $1(7.1)$ & 100 & $13(92.9)$ & $0(0.0)$ & $1(7.1)$ \\
\hline I. repens & 3 & $1(33.0)$ & 100 & $2(67.0)$ & $0(0.0)$ & $1(33.3)$ \\
\hline I. rubens & 10 & $2(20.0)$ & 50 & $8(80.0)$ & $0(0.0)$ & $1(10.0)$ \\
\hline I. sinensis & 231 & $31(13.0)$ & 67.8 & $200(87.0)$ & $7(3.5)$ & $28(12.1)$ \\
\hline I. spathulata & 27 & $2(7.4)$ & 100 & $25(92.6)$ & $2(8.0)$ & $4(14.8)$ \\
\hline I. stenobasis & 10 & $1(10.0)$ & 100 & $9(90.0)$ & $0(0.0)$ & $1(10.0)$ \\
\hline I. tenuirostris & 165 & $19(12.0)$ & 73.6 & $146(88.0)$ & $8(5.5)$ & $22(13.3)$ \\
\hline I. velutipes & - & - & - & - & - & - \\
\hline I. wightii & 51 & $6(12.0)$ & 50 & $45(88.0)$ & $1(2.2)$ & $4(7.8)$ \\
\hline H. sublobata & 267 & $22(8.2)$ & 63.6 & 245 (91.8) & $4(1.6)$ & $18(6.7)$ \\
\hline L. owariensis & 53 & $4(8.0)$ & 75 & $49(92.0)$ & $5(10.2)$ & $8(15.1)$ \\
\hline
\end{tabular}

a Dash (-) indicates that no observations and NCM-ELISA tests were conducted for a given species in the year 2007.

b Numbers in parenthesis represent the proportion of plants with virus-like symptoms as a percentage of total number of plants observed in a given year.

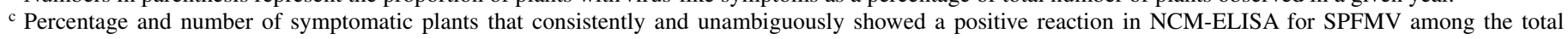
number of plants with virus-like disease symptoms in a given year.

${ }^{\mathrm{d}}$ Numbers in parenthesis represent the proportion of plants without virus-like symptoms as a percentage of total number of plants observed in a given year.

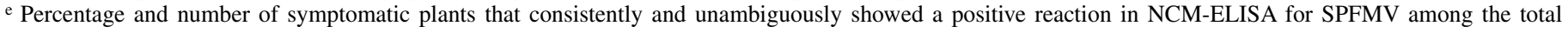
number of plants without virus-like disease symptoms in a given year. Numbers in parenthesis represent the percentage of symptomless plants infected with SPFMV. 
of SPFMV in surrounding sweetpotato fields in Uganda or the United States. Conversely, it is also unknown whether sweetpotato plants influence the epidemiology of SPFMV in the surrounding wild plant communities. New sweetpotato cultivations are established by taking cuttings from vines of the previous crops for planting, which makes sweetpotato a 'perennial' plant in the local cropping system. Although farmers usually manage to select symptomless and SPFMV-free vines for taking cuttings (30), the subsistence sweetpotato crops and especially the remaining plants from harvested crops and those growing in abandoned plots often are infected with SPFMV (29). The actual interactions of the wild species and sweetpotato crops in terms of virus transmission between them require further study.

The annual and perennial wild species were found to have equal incidences of SPFMV, which was unexpected because perennials whose lifecycles span several sweetpotato growing seasons were anticipated to have higher incidences of the virus. SPFMV is not known to be seed transmitted in sweetpotato. Presuming that this also holds true for the wild species, a theory which needs to be tested in future studies, the data indicate that aphid transmission of SPFMV occurs efficiently between the wild species or from sweetpotato to the annual species.

The survey of this study was carried out initially in 2004 and repeated 3 years later. Therefore, the results may provide a fair estimate of the incidence of virus-like diseases and SPFMV in wild species of Convolvulaceae in the different agroecological zones of Uganda. The eastern zone was the richest in terms of the number of different wild plant species. The eastern zone also consistently showed the highest proportions of plants expressing virus-like disease symptoms as well as the highest percentage of SPFMV-infected plants. The overall incidence of SPFMV was significantly higher in 2004 than in 2007. One possible explanation of the result could be the difference in the numbers of species assessed in the 2 years. Plants from 27 different species were assessed in 2004 compared with 19 species in 2007. In addition, out of 239 plants of the eight species that were exclusively collected from the eastern zone in 2004 , $38 \%$ were seropositive for SPFMV, making a $28 \%$ contribution toward the overall SPFMV seropositive plants in the first survey. Studies on BYDV have shown that species richness was of less importance in virus prevalence, whereas the presence of one highly suitable host species (Avena fatua) in a plant community significantly enhanced virus prevalence (62). Hence, in Uganda, it seems likely that one or more of the species encountered exclusively in the eastern zone could have influenced the difference between SPFMV incidences in 2004 and 2007.

The incidences of SPFMV in the wild species and sweetpotato crops were contradictory among three agroecological zones. Although the incidence of SPFMV in the wild species was highest in the eastern zone and lower in the central and western zones, the incidence in sweetpotato was low in the eastern zone and higher in the central and western zones according to previous studies $(3,5,53)$. Because all wild plants tested from the different agroecological zones grew in sweetpotato fields or their close proximity and most of them are perennial, incidences of SPFMV were expected to be positively correlated in the wild species and sweetpotato crops. However, this was the case only in the northern zone, where the wild species and sweetpotato crops were rarely infected with SPFMV according to this study and previous studies, respectively $(3,5,53)$. One explanation of the results could be isolation of the virus populations in wild species from those in sweetpotato; however, as discussed above in the context of SPFMV transmission by vectors, this scenario does not seem likely. The other explanation could be the putative negative impact of SPFMV on wild species as demonstrated for some viruses in nondomesticated host plants $(24,25,48,49,51,61)$, where failure to detect some viruses was due to death of infected individual plants (51). According to this hypothesis, high pressure with
SPFMV from the sweetpotato crops might result in natural selection for resistant genotypes in the wild species populations, especially in the central region at Lake Victoria basin and in the western zone. Indeed, in the central and western zones, sweetpotato plants are grown continuously all year around, with new and older crops overlapping (8), which facilitates spread of SPFMV in the crops (6) and maintains a high infection pressure. In contrast, sweetpotato growing is interrupted by a dry season in the northern zone and some districts of the eastern zone, where sweetpotato plants are grown in larger fields $(5,53)$.

In California, exotic introduced grass species are commonly infected with BYDVs or CYDVs and also increase virus incidence in the native perennial bunchgrasses that, consequently, are impaired in their survivorship in competition against the exotic grasses $(11,48-50)$. However, whether that has resulted in an increase of resistance to BYDVs and CYDVs in bermudagrass has not been reported. In Uganda, many local sweetpotato cultivars are resistant to SPFMV and succumb to a severe disease only when infected also with SPCSV $(3,4,41,42,54)$. Hence, in sweetpotato, there is evidence of selection for higher levels of resistance to SPFMV under a high infection pressure with the virus. The wild species also seemed to express tolerance to SPFMV, because a large proportion (42 and 38\% in the surveys of 2004 and 2007, respectively) of the SPFMV-infected wild plants did not display disease symptoms. This was observed for a number of species, most notably L. owariensis and I. cairica, for which up to 54 and $32 \%$ of symptomless plants, respectively, were found infected with SPFMV (Table 4). Large proportions of virus-positive but symptom-free (virus-tolerant) plants also have been reported in wild grasses $(18,64)$ and wild Brassica spp. (73). A previous study has shown that, indeed, some genotypes of $I$. cairica, I. involucrata, and I. hildebrandtii collected from the central zone (Mpigi) in Uganda are resistant to SPFMV (39). Therefore, the data of this study provide novel insights into a possible co-evolution of the local SPFMV strain (SPFMV-EA) and its wild hosts in East Africa, which will be an important subject for future studies.

\section{ACKNOWLEDGMENTS}

We thank A. L. Laine (University of Helsinki) for help with statistical analysis; A. L. Laine and J. N. Thompson (University of California) for helpful discussions and critical reading of the manuscript; S. Fuentes and L. F. Salazar (International Potato Center, Lima, Peru) for providing antibodies; R. Badaza and P. Ndolereire (Herbarium, Department of Botany, Makerere University) for technical assistance in taxonomic identification of the plant species; P. R. Rubaihayo (Department of Crop Science, Makerere University) for supporting the study; and the Academy of Finland (grants 1102134 and 1110797) for financial support.

\section{LITERATURE CITED}

1. Agnew, A. D. Q., and Agnew, S. 1994. Upland Kenya Wild Flowers: A Flora of the ferns and Herbaceous Flowering Plants of Upland Kenya. East Africa Natural History Society, Nairobi, Kenya.

2. Alvarez, J. M., and Srinivasan, R. 2005. Evaluation of hairly nightshade as an inoculum source for aphid-mediated transmission of potato leafroll virus. J. Econ. Entomol. 98:1101-1108.

3. Aritua, V., Adipala, E., Carey, E. E., and Gibson, R. W. 1998. The Incidence of sweetpotato virus disease (SPVD) and virus resistance of sweetpotato grown in Uganda. Ann. Appl. Biol. 132:399-411.

4. Aritua, V., Alicai, T., Adipala, E., Carey, E. E., and Gibson, R. W. 1998. Aspects of resistance to sweetpotato virus disease in sweetpotato. Ann. Appl. Biol. 132:387-398.

5. Aritua, V., Bua, B., Barg, E., Vetten, H. J., Adipala, E., and Gibson, R. W. 2007. Incidence of five viruses infecting sweetpotatoes in Uganda; the first evidence of Sweet potato caulimo-like virus in Africa. Plant Pathol. 56:324-331.

6. Aritua, V., Legg, J. P., Smit N. E. J. M., and Gibson, R. W. 1999. Effect of local inoculum on the spread of sweet potato virus disease: Limited infection of susceptible cultivars following widespread cultivation of a resistant sweetpotato cultivar. Plant Pathol. 48:655-661. 
7. Ateka, E. M., Njeru, R. W., Kibaru, A. G., Kimenju, J. W., Barg, E., Gibson, R. W, and Vetten, H. J. 2004. Identification and distribution of viruses infecting sweetpotato in Kenya. Ann. Appl. Biol. 144:371-379.

8. Bashasha, B., Mwanga, R. O. M., Ocitti p'Obwoya, C., and Ewell, P. T. 1995. Sweetpotato in the Farming and Food Systems of Uganda: A Farm Survey Report. International Potato Centre (CIP) and National Agricultural Research Organization (NARO), Lima, Peru.

9. Blundel, M. 1992. Collins Photo Guide. Wild Flowers of East Africa. Harper Collins, London.

10. Bock, K. R., Guthrie, E. J., and Figueiredo, G. 1981. A strain of cassava latent virus occurring in coastal districts of Kenya. Ann. Appl. Biol. 99:151-159.

11. Borer, E. T., Hosseini, P. R., Seabloom, E. W., and Dodson, A. P. 2007. Pathogen-induced reversal of native dominance in a grassland community. Proc. Nat. Acad. Sci. USA 104:5473-5478.

12. Brunt, A. A., Crabtree, K., Dallwitz, M. J., Gibbs, A. J., and Watson, L. 1996. Viruses of Plants. Descriptions and Lists from VIDE Database. CAB International, Wallingford, UK.

13. Burdon, J. J., Thrall, P. H., and Ericson, L. 2006. The current and future dynamics of disease in plant communities. Annu. Rev. Phytopathol. 44:19-39.

14. Byamukama, E., Gibson, R. W., Aritua V., and Adipala, E. 2004. Withincrop spread of sweetpotato virus disease and population dynamics of its whitefly and aphid vectors. Crop Prot. 23:109-116.

15. Clark, C. A., Derrick, K. S., Pace, C. S., and Watson, B. 1986. Survey of wild Ipomoea species as potential reservoirs of sweetpotato feathery mottle virus in Louisiana. Plant Dis. 70:931-932.

16. Cooper, J. I., and Jones, R. A. C. 2006. Wild plants and viruses: underinvestigated ecosystems. Adv. Virus Res. 67:1-47.

17. Cuellar, W. J., Tairo, F., Kreuze, J. F., and Valkonen, J. P. T. 2008. Analysis of gene content in Sweet potato chlorotic stunt virus RNA1 reveals the presence of p22 RNA silencing suppressor in only few isolates: implications to viral evolution and synergism. J. Gen. Virol. 89:573-582.

18. Davis, L. T., and Guy, P. L. 2001. Introduced plant viruses and the invasion of a native grass flora. Biol. Invas. 3:89-95.

19. FAOSTAT. 2007. FAO database. http://faostat.fao.org/site/567/default.aspx

20. Fargette, D., Konaté, G., Fauquet, C., Muller, E., Peterschmitt, M., and Thresh, J. M. 2006. Molecular ecology and emergence of tropical plant viruses. Annu. Rev. Phytopathol. 44:235-260.

21. Fargette, D., Lister, R. M., and Hood, E. L. 1982. Grasses as a reservoir of barley yellow dwarf virus in Indiana. Plant Dis. 66:1041-1045.

22. Farzadfar, S., Ahoonmanesh, A., Mosahebi, G. H., Paurrahim, R., and Golnaraghi, A. R. 2007. Occurrence and distribution of cauliflower mosaic virus on cruciferous plants in Iran. Plant Pathol. J. 6:22-29.

23. Feng, G., Gong, Y., and Zhang, P. 2000. Production and deployment of virus-free sweetpotato in China. Crop Prot. 19:105-111.

24. Friess, N., and Maillet, J. 1996. Influence of cucumber mosaic virus infection on intraspecific competitive ability and fitness of purslane (Portulaca oleracea). New Phytol. 132:103-111.

25. Funayama, S., Hikosaka, K., and Yahara, T. 1997. Effects of virus infection and growth irradiance on fitness components and photosynthetic properties of Eupatorium makinoi (Asteraceae). Am. J. Bot. 84:823-829.

26. Geddes, A. M. W. 1990. The relative importance of crop pests in SubSaharan Africa. Nat. Resour. Inst. Bull. No. 36. Natural Resources Institute, UK

27. Gibb, K. S., and Padovan, A. C. 1993. Detection of sweetpotato feathery mottle virus in sweetpotato grown in northern Australia using an efficient and simple assay. Int. J. Pest Manage. 39:223-228.

28. Gibbs, A., and Mackenzie, A. 1997. A primer pair for amplifying part of the genome of all potyvirids by RT-PCR. J. Virol. Methods 63:9-16.

29. Gibson, R. W., Mpembe, I., Alicai, T., Carey, E. E., Mwanga, R. O. M., Seal, S. E., and Veten, H. J. 1998. Symptoms, aetiology and serological analysis of sweet potato virus disease in Uganda. Plant Pathol. 47:95-102.

30. Gibson, R. W., Mwanga, R. O. M., Kasule, S., Mpembe, I., and Carey, E. E. 1997. Apparent absence of viruses in most symptomless field grown sweetpotato in Uganda. Ann. Appl. Biol. 130:481-490.

31. Gilbert, G. S. 2002. Evolutionary ecology of plant disease in natural ecosystems. Annu. Rev. Phytopathol. 40:13-43.

32. Gutiérrez, D. L., Fuentes, S., and Salazar, L. 2003. Sweet potato virus disease (SPVD): Distribution, incidence, and effect on sweet potato yield in Peru. Plant Dis. 87:297-302.

33. Guy, P. L., Johnson, G. R., and Morris, D. I. 1987. Barley yellow dwarf viruses in, and aphids on, grasses (including cereals) in Tasmania. Aust. J. Agric. Res. 38:139-152.

34. Ha, C., Revill, P., Harding, R. M., Vu, M., and Dale, J. L. 2008. Identification and sequence analysis of potyviruses infecting crops in Vietnam. Arch. Virol. 153:45-60

35. He, G., Prakash, C. S., and Jarret, R. L. 1995. Analysis of genetic diversity in a sweetpotato (Ipomoea batatas) germplasm collection using
DNA amplification fingerprinting. Genome 38:938-945.

36. Hobbs, H. A., Eastburn, D. M., D' Acry, C. J, Kindhart, J. D., Masiunas, J. B., Voegtlin, D. J., Weinzierl, R. A., and McCoppin, N. K. 2000. Solanaceous weeds as sources of Cucumber mosaic virus in southern Illinois for aphid transmission to pepper. Plant Dis. 84:1221-1224.

37. Izadpanah, K., Zaki-Aghl, M., Zhang, Y. P., Daubert, S. D., and Rowhani, A. 2003. Bermudagrass as a potential reservoir host for grapevine fan leaf virus. Plant Dis. 87:1179-1182.

38. Kahn, N. D., Walgenbach, J. F., and Kennedy, G. C. 2005. Summer weeds as hosts for Frankliniella occidentalis and Frankliniella fusca (Thysanoptera: Thripidae) as as reservoirs for Tomato spotted wilt tospovirus in North Carolina. J. Econ. Entomol. 98:1810-1815.

39. Karyeija, R. F., Gibson, R. W., and Valkonen, J. P. T. 1998. Resistance to sweetpotato virus disease (SPVD) in wild East African Ipomoea. Ann. Appl. Biol. 133:39-44.

40. Karyeija, R. F., Gibson, R. W., and Valkonen, J. P. T. 1998. The significance of sweetpotato feathery mottle virus in subsistence sweetpotato production in Africa. Plant Dis. 82:4-15.

41. Karyeija, R. F., Kreuze, J. F., Gibson, R. W., and Valkonen, J. P. T. 2000. Synergistic interactions of a potyvirus and a phloem-limited crinivirus in sweetpotato plants. Virology 269:26-36.

42. Karyeija, R. F., Kreuze, J. F., Gibson, R. W., and Valkonen, J. P. T. 2000. Two serotypes of sweetpotato feathery mottle virus in Uganda and their interaction with resistant sweetpotato cultivars. Phytopathology 90:12501255.

43. Kennedy, G. G., and Moyer, J. W. 1982. Aphid transmission and separation of two strains of sweetpotato feathery mottle virus from sweetpotato. J. Econ. Entomol. 75:130-133.

44. Kreuze, J. F., Karyeija, R. F., Gibson, R. W, and Valkonen, J. P. T. 2000. Comparisons of coat protein gene sequences show that East African isolates of sweet potato feathery mottle virus form a genetically distinct group. Arch. Virol. 145:567-574.

45. Legg, J. P. 1999. Emergence, spread and strategies for controlling the pandemic of cassava mosaic virus disease in East and central Africa. Crop Prot. 18:627-237.

46. Loebenstein, G., Fuentes, S., Cohen, J., and Salazar, L. F. 2003. Sweetpotato. Pages 223-248 in: Viruses and Virus-Like Diseases of Major Crops in Developing Countries. G. Loebenstein and G. Thottapilly, eds. Kluwer Academic Publishers, Dordrecht, The Netherlands.

47. Mabberley, D. J. 1987. The Plant Book. Cambridge University Press, Cambridge.

48. Malmstrom, C. M., Hughes, C. C., Newton, L. A., and Stoner, C. J. 2005. Virus infection in remnant native bunchgrasses from invaded California grasslands. New Phytol. 168:217-230.

49. Malmstrom, C. M., McCullough, A. J., Newton, L. A., Johnson, H. A., and Borer, E. T. 2005. Invasive annual grasses indirectly increase virus incidence in California native perennial bunchgrasses. Oecologia 145:153-164.

50. Malmstrom, C. M., Stoner, C. J., Brandenburg, S., and Newton L, A. 2006. Virus infection and grazing exert counteracting influences on survivorship of native bunchgrass seedlings competing with invasive exotics. J. Ecol. 94:264-275.

51. Maskell, L. C., Raybould, A. F., Cooper, J. I., Edwards, M.-L., and Gray, A. J. 1999. Effects of turnip mosaic virus and turnip yellow mosaic virus on survival, growth and reproduction of wild cabbage (Brassica oleracea). Ann. Appl. Biol. 135:401-407.

52. Moyer, J. W., and Salazar, L. F. 1987. Viruses and viruslike diseases of sweetpotato. Plant Dis. 73:451-455.

53. Mukasa, S. B., Rubaihayo, P. R., and Valkonen, J. P. T. 2003. Incidence of viruses and viruslike diseases of sweet potato in Uganda. Plant Dis. $87: 329-335$

54. Mukasa, S. B., Rubaihayo, P. R., and Valkonen, J. P. T. 2006. Interactions between a crinivirus, an ipomovirus and a potyvirus in co-infected sweetpotato plants. Plant Pathol. 55:458-467.

55. Mukasa, S. B., Tairo, F., Kullaya, A., Rubaihayo, P. R., and Valkonen, J. P. T. 2003. Coat protein sequence analysis reveals occurrence of new strains of sweetpotato feathery mottle virus in Uganda and Tanzania. Virus Genes 27:49-56.

56. Nault, L. R. 1997. Arthropod transmission of plant viruses: A new synthesis. Ann. Entomol. Soc. Am. 90:522-541.

57. Ng, J. C. K., and Falk, B. W. 2006. Virus-vector interactions mediating nonpersistent and semipersistent transmission of plant viruses. Annu. Rev. Phytopathol. 44:183-212.

58. Njeru, R. W., Mburu, M. W. K., Cheramgoi, E., Gibson, R. W., Kiburi, Z. M., Obodho, E., and Yobera, D. 2004. Studies on the physiological effects of viruses on sweet potato yield in Kenya. Ann. Appl. Biol. 145:71-76.

59. Norris, R. F., and Kogan, M. 2000. Interactions between weeds, arthropod pests, and their natural enemies in managed ecosystems. Weed Sci. 48:94158.

60. Powell, G., Tosh, C. R., and Hardie, J. 2006. Host plant selection by 
aphids: Behavioral, evolutionary, and applied perspectives. Annu. Rev. Entomol. 51:309-330.

61. Power, A. G. 2002. Ecological risks of transgenic virus-resistance crops. Pages 125-142 in: Genetically Engineered Organisms: Assessing Environmental and Human Health Effects. D. K. Letourneau and B. E. Burrows, eds. CRC Press, Boca Raton, FL.

62. Power, A. G., and Mitchell, C. E. 2004. Pathogen spillover in disease epidemics. Am. Nat. 164:S79-S89.

63. Power, A. G., and Remold, S. K. 1996. Incidence of barley dwarf virus in wild grass populations: implications for biotechnology risk assessment. In: Proceedings of the Biotechnology Risk Assessment, M. Levin, C. Grim, and S. Angle, eds. Balmar, Gaithersburg, MD.

64. Remold, S. K. 2002. Unapparent virus infection and host fitness in three weedy grass species. J. Ecol. 90:967-977.

65. SAS institute 1999. SAS/STAT Software User's Guide. Release 8.00. SAS Institute Inc., Cary, NC.

66. Schaefers, G. A., and Terry, E. R. 1976. Insect transmission of sweetpotato disease agents in Nigeria. Phytopathology 66:642-645.

67. Sheffield, F. M. L. 1953. Virus diseases of sweetpotato in parts of Africa. Emp. J. Exp. Agric. 21:184-189.

68. Sheffield, F. M. L. 1957. Virus diseases of sweetpotato in East Africa. Identification of the viruses and their insect vectors. Phytopathology 47:582-590.

69. Stubbs, L. L., and McLean, D. L. 1958. A note on aphid transmission of a feathery mottle virus of sweetpotato. Plant Dis. Rep. 42:216.

70. Tairo, F., Kullaya, A., and Valkonen, J. P. T. 2004. Incidence of viruses infecting sweetpotato in Tanzania. Plant Dis. 88:916-920.
71. Tairo, F., Mukasa, S. B., Jones, R. A. C., Kullaya, A., Rubaihayo, P. R., and Valkonen, J. P. T. 2005. Unravelling the genetic diversity of the three main viruses involved in sweetpotato virus disease (SPVD) and its practical implications. Mol. Plant Pathol. 6:199-211.

72. Taiwo, M. A., Hughes Jd'A., and Akomah, A. R. 2006. Natural infection of Datura stramonium L. by an unusual strain of Pepper veinal mottle virus genus Potyvirus in Nigeria. Plant Pathol. J. 5:401-404.

73. Thurston, M. I., Pallet, D. W., Cortina-Borja, M., Edwards, M.-L., Raybould, A. F., and Cooper, J. I. 2001. The incidence of viruses in wild Brassica nigra in Dorset (UK). Ann. Appl. Biol. 139:277-284.

74. Valverde, R. A., Clark, C. A., and Valkonen, J. P. T. 2007. Viruses and virus disease complexes of sweetpotato. Plant Viruses 1:116-126.

75. Valverde, R. A., Lozano, G., Navas-Castillo, J., Ramos, A., and Valdés, F 2004. First report of Sweet potato chlorotic stunt virus and Sweet potato feathery mottle virus infecting sweet potato in Spain. Plant Dis. $88: 428$.

76. Verdcourt, B. 1963. Convolvulaceae. Pages 1-161 in: Flora of Tropical East Africa. C. E. Hubbard and E. Milne-Redhead, eds. Whitefriars Press Ltd., London.

77. Webster, C. G., Coutts, B. A., Jones, R. A. C., Jones, M. G. K., and Wylie, S. J. 2007. Virus impact at the interface of an ancient ecosystem and a recent agroecosystem: Studies on three legume-infecting potyviruses in the southwest Australian floristic region. Plant Pathol. 56:729-745.

78. Wisler, G. C. 2005. Interactions between weeds and cultivated plants as related to management of plant pathogens. Weed Sci. 53:914-917.

79. Woolfe, J. A., ed. 1992. Sweetpotato, an Untapped Food Resource. Cambridge University Press, New York. 